\title{
FAKTOR PENENTU PENGALIHAN SERTIFIKAT TANAH HASIL PROGRAM REDISTRIBUSI (KASUS PADA PETANI DI DESA KAROSSA KECAMATAN TASSOKO KABUPATEN MAMUJU SULAWESI BARAT)
}

\author{
M. Unu Ibnudin \\ Kantor Pertanahan Kota Bandung, Bandung \\ Program Pascasarjana Manajemen dan Bisnis, Institut Pertanian Bogor, Bogor \\ E-mail: uibnudin@yahoo.com
}

\begin{abstract}
ABSTRAK. Meningkatnya kebutuhan tanah untuk pembangunan, baik yang dikelola oleh pemerintah, swasta dan individu memerlukan kepastian hukum. Berbagai program sudah dijalankan oleh Badan Pertanahan untuk meningkatkan terwujudnya Jaminan Kepastian Hukum Hak Atas Tanah, salah satunya adalah Legalisasi aset. Program ini di Desa Tassoko Kecamatan Karrosa Kabupaten Mamuju pada Tahun 2013 dan Tahun 2014 berturut turut sebanyak 500 bidang dan 800 bidang. Tujuan Penelitian ini adalah untuk Mengidentifkasi karakteristik peserta program, mengidentifikasi kondisi dan isu petani mengalihkan sertipikat kepada pihak lain, dan menganalisis faktor-faktor yang berpengaruh terhadap keputusan petani untuk mengalihkan sertipikat kepada pihak lain setelah pelaksananaan kegiatan redistribusi tanah. Hasil analisis deskriptif menunjukkan bahwa jumlah petani yang sudah mengalihkan sertipikatnya dengan cara menjual kepada pihak lain mencapai $28,9 \%$, sedangkan yang belum mengalihkan lahannya sebanyak 71,1\%.Petani penerima redistribusi mayoritas berpendidikan lebih dari SD (51,8\%), berumur lebih dari 40 tahun (60,2\%), berjenis kelamin lak-laki (74,7\%), memiliki lebih dari satu bidang tanah (50,6\%), melakukan kerjasama dengan kelompok tani (74,7\%), memiliki tingkat kemiskinan yang tinggi $(73,5 \%)$ dan sebagian besarnya dipengaruhi pihak luar. Hasil uji hipotesis menunjukkan bahwa bahwa faktor penentu yang mempengaruhi keputusan petani mengalihkan sertipikat tanah hasil program retribusi adalah jenis kelamin laki-laki, tingkat kemiskinan dan pengaruh pihak luar, sedangkan empat faktor lainnya yakni pendidikan, umur, jumlah bidang tanah yang dimiliki dan kerjasama dengan kelompok tani dinyatakan tidak berpengaruh.
\end{abstract}

Kata kunci: tanah, BPN, landreform, redistribusi

ABSTRACT. The increasing need for land for development, both managed by the government, private sector and individuals need legal certainty. Various programs have been executed by the Land Board to increase the realization of Security Land Rights rLegal Certainty, one of which was Legalization assets. The program is in the village Tassoko Karrosa District of Mamuju in the year 2013 and 2014 respectively 500 fields and 800 fields. Purpose of this study was to Identifying characteristics of the participants, identifying the conditions and the issue of farmers divert certificate to another party, and analyzes the factors that influence the farmer's decision to transfer the certificate to another party after pelaksananaan activities of land redistribution. The finding result shows there is $28.9 \%$ certificate been transferred to the party for various reasons. Majority of the receiver farmers are having the education of more than ES (51.8\%), older than 40 years (60.2\%), having male gender (74.7\%), having more than one parcel of land (50.6\%), conducting the cooperation with farmer group (74.7\%), having the high poverty rate (73.5\%), and majority influenced by outsiders. The hypotesis testing shows that only Gender $\left(X_{3}\right)$, Poverty Level $\left(X_{0}\right)$ and the influence of outsiders $\left(X_{7}\right)$ affect the farmers to transfer the certificate to other parties, while the educational level $\left(X_{1}\right)$, age $\left(X_{2}\right)$, and number of parcel of land owned $\left(X_{4}\right)$ have no effect.

Key words: land, BPN, landreform, redistribution

\section{PENDAHULUAN}

Menurut Soetrisno (1995) di dalam kehidupan manusia Indonesia, tanah (land) mempunyai peran yang sangat penting. Terdapat tiga kebutuhan hidup manusia Indonesia yang pemenuhannya akan selalu berkaitan dengan tanah, yaitu, pertama, manusia Indonesia membutuhkan tanah untuk memperoleh pendapatan guna menunjang kehidupan mereka; kedua, manusia membutuhkan tanah untuk mendirikan rumah tempat tinggal mereka; ketiga, manusia membutuhkan tanah untuk tempat tinggalnya yang terakhir pada saat mereka harus mengakhiri hidup mereka di dunia ini. Pemahaman dari ungkapan itu, menunjukan bahwa "tanah" adalah tempat aktivitas seluruh kehidupan manusia berlangsung, untuk kegiatan ekonomi (tempat tinggal, mencari nafkah, kegiatan pertanian, rekreasi dan berbagai aktivitas sosial lainnya) atau tanah dengan hak kepemilikannya bagi masyarakat Indonesia merupakan sumber daya (faktor produksi) yang sangat penting bagi hidup dan akhir hidupnya nanti.

Seiring dengan bertambahnya jumlah penduduk dan pergeseran budaya manusia Indonesia terhadap pengakuan norma dan hukum hak kepemilikan tanah, yang pada awalnya cenderung kepada pengakuan fungsi sosial, namun saat ini telah berubah lebih kepada fungsi ekonomi dengan values yangdibentuk dari budaya itu sendiri. Meningkatnya kebutuhan tanah untuk pembangunan khususnya pengembangan kota dan wilayah, baik yang dikelola oleh pemerintah atau pemilik modal (swasta), ditujukan bagi kepentingan dan pemberdayaan ekonomi masyarakat. Namun pada kenyataannya banyak memunculkan persoalan tentang kepastian hukum atas hak milik tanah yang kompleks 
dan strategis, yang juga selalu berkaitan dengan masalah ekonomi, politik dan keamanan secara nasional. Dimana dua-pertiga dari penduduk miskin dunia merupakan kaum miskin pedesaan. Kemiskinan dan ketidakmerataan masih merupakan wajah pedesaan yang utama. Selama dalam beberapa dekade, hal ini telah menantang untuk dibuat kebijakan melalui usaha yang terus menerus dari pemerintah nasional, institusi internasional dan masyarakat sipil. Penguasaan yang efektif atas sumber daya produktif, terutama atas tanah oleh kaum miskin di pedesaan penting sekali bagi kapasitas mereka untuk membangun mata pencaharian pedesaan dan mengatasi kemiskinan. Hal ini dikarenakan dibanyak negara yang berlatar agraris porsi yang berarti dari pendapatan kaum miskin pedesaan masih berasal dari pertanian, meskipun telah terjadi proses diversifikasi mata pencaharian di tempat-tempat yang berbeda dari waktu ke waktu. Oleh karena itu, ketiadaan akses tanah sangat kuat kaitannya dengan kemiskinan dan ketidakmerataan.

Menurut Borras (2008) pengaruh berbagai kebijakan pertanahan dan ragam strategi serta pendekatan untuk mengimplementasikannya, terhadap pengurangan kemis-kinan dan ketimpangan sosial diwilayah pedesaan, akan didapat identifikasi pilihan alternatif kebijakan yang mungkin dilaksanakan. Yaitu konseptualisasi tentang landreform redistribusif yang meliputi sertipikasi tanah (land titling), restitusi tanah adat, klaim-klaim tanah adat, land settlement, perjanjian sewa menyewa dan tenansi, konsolidasi dan persilisasi tanah.

Masalah pertanahan tidak lagi hanya menyangkut akses seseorang untuk dapat memiliki sebidang tanah, tetapi lebih kepada persoalan penghargaan atau penggantian (harga jual) yang wajar atas hak milik tanah yang dipindahtangan kepemilikannya, baik masyarakat kepada masyarakat (pemilik modal) ataupun masyarakat kepada pemerintah yang akan menggunakan tanah untuk tujuan pembangunan. Sebagai pengelola pembangunan, pemerintah memerlukan tanah untuk melaksanakan proyek-proyeknya. Pembangunan sebagai salah satu aspek yang diprioritaskan pemerintah dalam kerangka meningkatkan kesejahteraan rakyat, justru seringkali menimbulkan dampak sebaliknya. Bahkan banyak warga masyarakat yang terpaksa atau tidak untuk melepaskan tanah miliknya bagi pembangunan, tetapi tidak mendapat penghargaan atau penggantian yang wajar atas tanah yang pemah dimilikinya. Tanah merupakan aset yang dapat dimiliki oleh perseorangan, masyarakat, badan hukum maupun pemerintah. Untuk menunjukkan kepemilikannya secara hukum maka aset-aset berupa tanah ini harus diformalisasikan, yaitu dengan dilakukan legalisasi aset.Legalisasi menurut Kamus Besar Bahasa Indonesia mempunyai arti penge-sahan (menurut undangundang atau hukum); sedangkan aset artinya sesuatu yang mempunyai nilai tukar atau modal; kekayaan. Jadi legalisasi aset mempunyai nilai tukar atau kekayaan/ modal (menurut undang-undang atau hukum).
Sektor pertanian merupakan tumpuan hidup bagi hampir seluruh rakyat Indonesia. Perekonomian Indonesia akan memiliki fundamental yang kuat jika ekonomi rakyat telah menjadi pelaku utama yang produktif dan berdaya saing dalam perekonomian nasional. Sektor pertanian merupakan representasi rakyat Indonesia dalam kehidupan ekonomi nasional, sehingga perlu diberikan prioritas yang tinggi dalam pembangunan nasional. Sektor pertanian merupakan area ekonomi yang melibatkan kepentingan rakyat banyak. Kondisi ini juga mengakibatkan sektor pertanian sering dihadapkan pada berbagai masalah yang menghambat produktivitasnya. Permasalahan utama adalah kurangnya modal, dalam hal ini tanah selain sebagai faktor komoditas juga dapat dimanfaatkan untuk dijadikan modal, dengan syarat tanah tersebut memiliki suatu hak dengan dibuktikan oleh tanda bukti hak yang resmi yang dapat diagunkan sebagai jaminan kredit untuk pengembangan usaha tani. Salah satu yang dilakukan oleh pemerintah dalam rangka peningkatan akses permodalan ke perbankan adalah program sertifikasi tanah.

Sertipikat merupakan salah satu jaminan yang dapat diterima oleh bank karena dianggap memenuhi persyaratan yuridis maupun ekonomis. Terpenuhinya persyaratan tersebut, dimaksudkan agar dalam pelunasan piutangnya terpenuhi oleh pemberian prestasi debitur dan terlindunginya secara hukum dalam eksekusi jaminan. Dari uraian tersebut di atas dapat dikatakan bahwa kurangnya modal bagi petani dalam meningkatkan usahanya dikarenakan tidak adanya akses kepada pihak perbankan untuk memperoleh pinjaman/kredit.

Desa Tassoko merupakan salah satu daerah pertanian di Kabupaten Mamuju dengan luas wilayah $175.32 \mathrm{Km}^{2}$ atau 15.40 persen dari luas Kecamatan Karrosa dengan jumlah penduduk 23.104 jiwa (perempuan sebanyak 11.188 jiwa dan laki-laki 23.104 jiwa). Kegiatan pen-sertipikatan tanah melalui program redistribusi tanah sejak tahun 2010 sampai dengan 2014 di desa Tassoko mulai dilakukan pada Tahun 2013 dan Tahun 2014 dengan masing-masing target 500 bidang dan 800 bidang. Desa Tassoko adalah desa yang memiliki target kegiatan redistribusi tanah lebih banyak dibandingkan dengan desa-desa yang lain yang menjadi lokasi pensertipikatan tanah melalui kegiatan redistribusi tanah. Hal menjadi permasalahan adalah masyarakat enggan memanfaat sertipikat hak atas tanah sebagai agunan bank guna memperoleh model usaha. Sebaliknya, banyaknya masyarakat, khususnya penerima retribusi tanah yang mengalihkan sertipikatnya kepada pihak lain dalam rangka memperoleh modal atau pengembangan usaha, yang ada (488.765 bidang tanah).

Selain dari kegiatan rutin yang dilaksanakan di Kantor Pertanahan Kabupaten Mamuju, kegiatan percepatan legalisasi aset juga dilaksanakan dengan kegiatan Prog-ram Nasional Agraria (PRONA), Usaha Menengah Kecil (UMK), Nelayan, Masyarakat Berpenghasilan 
Rendah (MBR), dan Redistribusi Tanah. Dari kegiatan legalisasi aset ini maka diharapkan bidang-bidang tanah yang ada di Kabupaten Mamuju akan memiliki kekuatan hukum yang kuat karena telah diterbitkannya sertipikat hak atas tanah.

Dari pengalaman-pengalaman kegiatan legalisasi aset setiap tahun yang diselenggarakan oleh Kantor Pertanahan Kabupaten Mamuju, antusiasme masyarakat untuk mengikuti kegiatan ini sangat rendah walaupun kegiatan penyuluhan telah dilaksanakan. Seperti wawancara yang dilakukan dengan Kepala Desa terkait dikatakan bahwa, masyarakat yang sebagian besar adalah petani masih belum bisa berperan secara aktif dalam mensertipikatkan tanahnya. Masalah lain adalah masyarakat masih enggan untuk memanfaatkan sertipikat hak atas tanah yang dimiliki untuk dimanfaatkan sebagai agunan di bank. Ada beberapa masyarakat yang lebih memilih untuk mengalihkan sertipikat tanahnya kepada pihak lain dalam rangka memperoleh modal usaha atau pengembangan usaha tani. Berdasarkan latar belakang di atas dan fenomen yang terjadi di desa Karossa tersebut, maka dianggap perlu melakukan penelitian dengan judul Faktorfaktor Mempengaruhi Petani Mengalihkan Sertipikat Tanah Hasil Program Redistribusi di Desa Karossa Kecamatan Tassoko Kabupaten Mamuju. Adapun rumusan masalah penelitian sebagai berikut: Bagaimana gambaran karakteristik peserta program legalisasi aset di Kabupaten Mamuju. Bagaimana kondisi sebenarnya isu petani untuk mengalihkan sertipikat kepada pihak lain pada peserta program legalisasi aset di Kabupaten Mamuju. Dan faktor-faktor apa yang mempengaruhi petani untuk mengalihkan sertipikat kepada pihak lain?

\section{METODE}

Pendekatan yang digunakan dalam penelitian ini melalui pendekatan survei dan kualitatif dengan indepth interview. Pendekatan Survei dengan menggunakan kuesioner sebagai instrumen atau alat pengumpul data, guna mengamati dan mendapatkan keterangan-keterangan yang jelas terhadap suatu masalah tertentu yang diteliti. Dalam penelitian ini akan dilakukan wawancara secara mendalam dengan panduan kuesioner (Lampiran 1) kepada sampel penelitian. Wawancara mendalam dilakukan secara sengaja kepada kepada masyarakat yang terpilih dan mau dari penerima target kegiatan redistribusi tanah yang sudah diberikan sebanyak 500 bidang.

Teknik pengumpulan data dan informasi adalah wawancara terstruktur menggunakan kuesioner, berupa pedoman wawancara dalam daftar isian kuesioner yang telah disiapkan untuk diisi atau dijawab oleh responden yang telah ditentukan.

Pengumpulan data primer ini menggunakan teknik participatory approach. Dalam pelaksanaannya, pene-liti bertemu langsung dengan responden baik secara individual maupun berkelompok. Selanjutnya peneliti memberikan penjelasan secara umum mengenai pene-litian. Setelah responden merasa tidak ragu dalam memberikan tanggapan, selanjutnya peneliti membacakan item-item pernyataan dalam kuesioner serta menjelaskan maksud yang terkandung di dalamnya sambil menuliskan tanggapan responden. Pembacaan item secara langsung ini dilakukan karena ada kecenderungan responden merasa kesulitan di dalam melakukan pengisian kuesioner. Hal ini dapat dimaklumi mengingat karakteristik responden ini secara umum memiliki tingkat pendidikan Sekolah Dasar.

Data sekunder didapatkan melalui literaturliteratur atau data-data, baik dari Kantor Pertanahan Kabupaten Mamuju, Kantor Desa, Kantor Badan Pusat Statistik (BPS) Kabupaten Mamuju, Pemerintah Daerah Kabu-paten Mamuju, dengan cara pengutipan dari dokumen resmi instansi atau sumber lainnya.

Teknis analisis penelitian dilakukan dengan meng-gunakan analisis deskriptif, regresi logistik dan uji Chi-Square, serta beberapa tools analysis lainnya yang mungkin digunakan.

\section{HASIL DAN PEMBAHASAN}

\section{Karakteristik Peserta Pro program legalisasi aset di Kabupaten Mamuju}

Status kepemilikan tanah hasil redistribusi tanah yang dilakukan di desa Tasokko, Kecamatan Karossa tidak lagi dimiliki oleh petani penggarap penerima hasil kegiatan redistribusi tanah, sebanyak 28.9 persen telah dialihkan kepihak lain walaupun peruntukkannya tetap difungsikan sebagai kebun. Proses peralihan haknya dilakukan dengan jual beli dibawah tangan dengan berbagai alasan diantaranya untuk modal usaha, biaya pendidikan anak, dan biaya pengobatan. Sebanyak 71.1 persen petani penggarap yang masih menguasai dan mengusahakan tanahnya secara aktif

Tujuan utama responden dalam mengikuti kegiatan legalisasi aset adalah untuk memiliki kepastian hukum, dari semua responden yang merupakan petani penggarap telah memahami arti pentingnya sertipikat. $100 \%$ dari responden memilih bahwa sertipikat memiliki kepastian hukum guna menghindari terjadinya sengketa tanah dikemudian hari. Faktor pendidikan, jenis kelamin, usia, dan ketidaktahuan mereka dalam biaya pembuatan sertipikat tidak menjadi hambatan dalam keikutsertaan mereka dalam mensertipikatkan tanahnya

\section{Keputusan Petani untuk Mengalihkan Sertipikat kepada Pihak Lain pada Peserta Program Legalisasi Aset Kegiatan Redistribusi Tanah di Kabupaten Mamuju}

Tabel 1. disimpulkan bahwa pendidikan tidak berpengaruh signifikan terhadap keputusan petani untuk mengalihkan sertipikat hak atas tanah kepada pihak lain. 
Hasil tersebut didukung oleh hasil tabulasi silang anatara Tingkat Pendidikan $\left(\mathrm{X}_{1}\right)$ dengan Keputusan Peralihan Hak SHM (Y) pada Tabel 1.

Tabel 1. Hubungan pendidikan dengan peralihan hak SHM ke pihak lain

\begin{tabular}{llll}
\hline & \multicolumn{2}{l}{ Peralihan Hak } & \\
\cline { 2 - 3 } Pendidikan & Belum & Telah & Jumlah \\
& Mengalihkan & Mengalihks & \\
& n & \\
\hline SD & $28(33,79 \%)$ & $12(14,5 \%)$ & $40(48,2 \%)$ \\
$>$ SD & $31(37,3 \%)$ & $12(14,5 \%)$ & $43(51,89 \%)$ \\
\hline Jumlah & $59(71,1 \%)$ & $24(28,9 \%)$ & $83(100 \%)$ \\
\hline
\end{tabular}

Hasil ini memperkuat hasil analisis bahwa tingkat pendidikan tidak berpengaruh signifikan terhadap keputusan petani untuk mengalihkan sertipikat kepada pihak lain. Hal ini semakin jelas relevan dengan hasil regressi logistic dan odd rationya.

Tabel 2. Hubungan umur dengan peralihan hak SHM ke pihak lain

\begin{tabular}{|c|c|c|c|}
\hline \multirow[b]{2}{*}{ Umur } & \multicolumn{2}{|l|}{ Peralihan Hak } & \multirow[b]{2}{*}{ Jumlah } \\
\hline & $\begin{array}{l}\text { Belum } \\
\text { Mengalihkan }\end{array}$ & $\begin{array}{l}\text { Telah } \\
\text { Mengalihlkan }\end{array}$ & \\
\hline$\leq 40$ tahun & $23(27.7 \%)$ & $10(12.0 \%)$ & $33(39.8 \%)$ \\
\hline$>40$ tahun & $36(43.496)$ & $14(16.9 \%)$ & $50(60.2 \%)$ \\
\hline Jumlah & $59(71.1 \%)$ & $24(28.9 \%)$ & $83(100 \%)$ \\
\hline
\end{tabular}

Tabel 2. menunjukkan bahwa umur tidak berpengaruh signifikan terhadap keputusan petani untuk mengalihkan sertipikat hak atas tanah kepada pihak lain. Namun demikian secara hubungan silang antara umur dan status peralihan Hak SHM ke pihak lian dapat dilihat pada Tabel 2.

Hasil ini memperkuat hasil analisis bahwa umur tidak berpengaruh signifikan terhadap keputusan petani untuk mengalihkan sertipikat hak atas tanah kepada pihak lain

Tabel 3. hasil analisis regresi logistik, diketahui nilai p-value yang dihasilkan untuk variabel jenis kelamin sebesar 0.073 . Nilai ini kurang dari 0.10 sehingga dapat disimpulkan bahwa jenis kelamin berpengaruh signifikan terhadap keputusan petani untuk mengalihkan sertipikat hak atas tanah kepada pihak lain. Secara rinci hubungan antara Jenis Kelamin dan Status Peralihan Hak SHM dapat dilihat pada Tabel 3 .

Tabel 3. Hubungan jenis kelamin dengan status peralihan hak

\begin{tabular}{lccc}
\hline \multirow{2}{*}{ Jenis Kelamin } & \multicolumn{2}{c}{ Status Peralihan Hal: } & \multirow{2}{*}{ Jumlah } \\
\cline { 2 - 3 } & $\begin{array}{c}\text { Belum } \\
\text { Mengalihkan }\end{array}$ & $\begin{array}{c}\text { Telah } \\
\text { Mengalihkan }\end{array}$ & \\
\hline Perempuan & $12(14.5 \%)$ & $9(10.89 \%)$ & $21(25.3 \%)$ \\
Laki-laki & $47(56.6 \%)$ & $15(18.1 \%)$ & $62(74.7 \%)$ \\
\hline Jumlah & $59(71.1 \%)$ & $24(28.9 \%)$ & $83(100 \%)$ \\
\hline
\end{tabular}

Hasil ini memperkuat hasil analisis bahwa jenis kelamin berpengaruh signifikan terhadap keputusan petani untuk mengalihkan sertipikat hak atas tanah kepada pihak lain.
Dari tabel hasil analisis regresi logistik, diketahui nilai p-value yang dihasilkan untuk variabel jumlah bidang yang dimiliki sebesar 0.327 . Nilai ini lebih besar dari 0.10 sehingga dapat disimpulkan bahwa jumlah bidang tanah yang dimiliki tidak berpengaruh signifikan terhadap keputusan petani untuk mengalihkan sertipikat hak atas tanah kepada pihak lain. Tabulasi silang hubungan kedua variabel tersebut dapat dilihat secara rinci pada Tabel 4.

Tabel 4. Hubungan jumlah bidang tanah yang dimiliki dengan status peralihan hak

\begin{tabular}{|c|c|c|c|}
\hline \multirow{2}{*}{$\begin{array}{c}\text { Jumlah Bidang Tanah } \\
\text { yang Dimiliki }\end{array}$} & \multicolumn{2}{|c|}{ Peralihan Hak: } & \multirow[b]{2}{*}{ Jumlah } \\
\hline & Belum Mengalihkan & $\begin{array}{c}\text { Telah } \\
\text { Mengalihkan }\end{array}$ & \\
\hline 1 Bidang & $26(31.3 \%)$ & $15(18.1 \%)$ & $41(49.4 \%)$ \\
\hline$>1$ Bidang & $33(39.8 \%)$ & $9(10.8 \%)$ & $42(50.6 \%)$ \\
\hline Jumlah & $59(71.1 \%)$ & $24(28.9 \%)$ & $83(100 \%)$ \\
\hline
\end{tabular}

Hasil ini memperkuat hasil analisis bahwa jumlah bidang tanah yang dimiliki tidak berpengaruh signifikan terhadap keputusan petani untuk mengalihkan sertipikat hak atas tanah kepada pihak lain.

Dari tabel hasil analisis regresi logistik, diketahui nilai $\mathrm{p}$-value yang dihasilkan untuk variabel kerjasama dengan kelompok tani sebesar 0,218. Nilai ini lebih besar dari 0.10 sehingga dapat disimpulkan bahwa kerjasama dengan kelompok tani tidak berpengaruh signifikan terhadap keputusan petani untuk mengalihkan sertipikat hak atas tanah kepada pihak lain. Namun demikian dapat dijelaskan tabulasi silang antara kedua variabel tersebut seperti dijelaskan pada Tabel 5.

Tabel 5. Hubungan silang kerjasama dengan kelompok tani dengan status peralihan hak

\begin{tabular}{|c|c|c|c|}
\hline \multirow{2}{*}{$\begin{array}{l}\text { Kerjasama dengan } \\
\text { Kelompok Tani }\end{array}$} & \multicolumn{2}{|c|}{ Status Peralihan Hak } & \multirow{2}{*}{ Jumlah } \\
\hline & Belum Mengalihkan & Telah Mengalihksan & \\
\hline Tidak & $15(18.1 \%)$ & $6(7.2 \%)$ & $21(25.3 \%)$ \\
\hline $\mathrm{Ya}$ & $44(53.0 \%)$ & $18(21.7 \%)$ & $62(74.7 \%)$ \\
\hline Jumlah & $59(71.1 \%)$ & $24(28.9 \%)$ & $83(100 \%)$ \\
\hline
\end{tabular}

Hasil ini memperkuat hasil analisis bahwa kerjasama dengan kelompok tani tidak berpengaruh signifikan terhadap keputusan petani untuk mengalihkan sertipikat hak atas tanah kepada pihak lain.

Berdasarkan hasil regresi logistik Tabel 6. menunjukkan terdapat pengaruh tingkat kemiskinan terhadap keputusan mengalihkan SHM ke pihak lain. Hal ini diperjelaskan oleh hasil tabulasi silang antaran tingkat kemiskinan dengan status peralihan SHM. Secara rinci dapat dilihat pada Tabel 6.

Tabel 6. Hubungan silang kerjasama dengan tingkat kemiskinan dengan status peralihan hak

\begin{tabular}{lcccccc}
\hline Tingkat & \multicolumn{3}{c}{ Status Pengalihan Hak } & \multicolumn{2}{c}{ Total Responden } \\
\cline { 2 - 7 } Keniskinan & Belum & $\%$ & Telah & $\%$ & Jumlah & $\%$ \\
\hline Sangat Niskin & 4 & 4.8 & 3 & 3.6 & 7 & 8.4 \\
Miskin & 15 & 18.1 & 5 & 6.0 & 20 & 24.1 \\
Cukup & 25 & 30.1 & 9 & 10.8 & 34 & 41.0 \\
Kaya & 11 & 13.3 & 5 & 6.0 & 16 & 19.3 \\
Sangat Kaya & 5 & 6.0 & 1 & 1.2 & 6 & 72 \\
\hline Total & 60 & 72.3 & 23 & 27.7 & 83 & 100.0 \\
\hline
\end{tabular}


Hal ini menunjukkan bahwa regresi Tabel 6. yang menyatakan tingkat kemiskinan berpengaruh terhadap status pengalihan Hak SHM, semakin miskin status sosial ekonomi petani, maka berpotensi lebih besar untuk memutuskan mengalihkan SHMnya ke pihak lain.

Tabel 7. Hubungan silang kerjasama dengan pengaruh pihak lain dengan status peralihan hak

\begin{tabular}{ccccccc}
\hline \multirow{2}{*}{$\begin{array}{c}\text { Peran Pengaruh Pihak } \\
\text { Luar }\end{array}$} & \multicolumn{3}{c}{ Status Pengalihan Hak: } & \multicolumn{3}{c}{ Total Responden } \\
\cline { 2 - 7 } & Belum & $\%$ & Telah & $\%$ & Jumlah & $\%$ \\
\hline Tidak ada & 57 & 68.7 & 8 & 9.6 & 65 & 78.3 \\
Ada & 3 & 3.6 & 15 & 18.1 & 18 & 21.7 \\
\hline Total & 60 & 72.3 & 23 & 27.7 & 83 & 100.0 \\
\hline
\end{tabular}

Berdasrkan hasil regresi logistik Tabel 7. juga menun-jukkan terdapat pengaruh peran/pengaruh pihak lain terhadap keputusan mengalihkan SHM kepada pihak lain. Hal ini diperjelaskan oleh hasil tabulasi silang antaran tingkat kemiskinan dengan status peralihan SHM. Secara rinci dapat dilihat pada Tabel 7.

Tabel 7. menunjukkan adanya pengaruh pihak lain lebih besar jumlah dan prosentasenya yang telah meng-alihkan SHMnya ke pihak lain dibandingkan dengan petani yang tidak dipengaruhi sama sekali. Hal ini memperkuat bahwa regresi adanya pengaruh pihak lain berpotensi besar dapat mempengaruhi status pengalihan Hak SHM. Semakin besar dorongan atau pengaruh pihak luar maka potensi untuk memutuskan mengalihkan SHMnya ke pihak lain akan semakin besar.

\section{Faktor PenentuPengalihan Sertifikat Tanah Hasil Program Redistribusi}

Faktor penentu yang mempengaruhi keputusan responden untuk mengalihkan sertipikat hak atas tanah berdasarkan pada tujuh variabel yang dianalisis. Ketujuh variabel tersebut adalah tingkat pendidikan $\left(\mathrm{X}_{1}\right)$, umur $\left(\mathrm{X}_{2}\right)$, jenis kelamin $\left(\mathrm{X}_{3}\right)$, jumlah bidang tanah yang dimiliki $\left(\mathrm{X}_{4}\right)$, apakah telah bekerjasama dengan kelompok tani dalam mengusahan tanahnya $\left(\mathrm{X}_{5}\right)$. Tingkat kemiskinan $\left(\mathrm{X}_{6}\right)$ dan Ada peran/pengaruh pihak luar $\left(\mathrm{X}_{7}\right)$. Variabel dependen (Y) dalam penelitian ini adalah keputusan responden dalam hal ini petani untuk mengalihkan sertipikat tanah yang telah dimiliki kepihak lain. Berdasarkan hasil analisis regresi logistikbiner menunjukkan bahwa hanya Jenis Kelamin $\left(\mathrm{X}_{3}\right)$, Tingkat Kemiskinan $\left(\mathrm{X}_{6}\right)$ dan peran/ pengaruh pihak luar $\left(\mathrm{X}_{7}\right)$ yang berpengaruh terhadap petani mengalih sertipikatnya pada tarap nyata (alpha) $0.1(10 \%)$, sedangkan tingkat pendidikan $\left(\mathrm{X}_{1}\right)$, umur $\left(\mathrm{X}_{2}\right)$, dan jumlah bidang tanah yang dimiliki $\left(\mathrm{X}_{4}\right)$ tidak berpengaruh.

Berdasarkan Tabel 8. model hasil Regresi Logistik "Binary Logit" menunjukkan hasil koefisien estimasi (estimasi parameter), standar error koefisien (Lampiran 2), nilai Z, dan $P$-value. Dalam penggunaan fungsi logit juga akan diperoleh hasil perhitungan odds rationya (perbandingan risiko) atau adjusted probability (probabilitas terjadi) dan selang kepercayaan 90\% untuk odds ratio. Hasil tersebut dapat dijelaskan bahwa responden dengan pendidikan SD maupun pendidikan yang lebih tinggi sama-sama berpeluang berpeluang untuk mengalihkan hak atas tanahnya 1 kali, namun peluang tersebut masih belum signifikan, yang ditunjukkan oleh $p$-value sebesar 0.999 yang lebih besar dari 0,10 . Artinya tinggi rendahnya tingkat pendidikan petani tidak mempengaruhi dia menglihkan SHMnya atau tidak, namun lebih cenderung disbebkan factor atau kebutuhan lain.

Tabel 8. Model regresi logistik biner yang mempengaruhi petani untuk mengalihkan sertipikat hak atas tanahnya.

\begin{tabular}{ccccc}
\hline Predictor & Koef Regresi & $Z$ & $\mathrm{P}$ & Odds Ratio \\
\hline Constant & 0.06941 & 0.03 & 0.977 & \\
X1 & 0.00045 & 0.00 & 0.999 & 1.00 \\
X2 & -0.00515 & -0.14 & 0.891 & 0.99 \\
X3 & 1.64815 & 1.79 & 0.073 & 5.20 \\
X4 & -1.25264 & -0.98 & 0.327 & 0.29 \\
X5 & 1.24220 & 1.23 & 0.218 & 3.46 \\
X6 & -1.27968 & -2.17 & 0.030 & 0.28 \\
X7 & 6.47447 & 3.95 & 0.000 & 648.38 \\
\hline
\end{tabular}

Demikian juga responden yang berumur lebih dari 40 tahun sedikit lebih kecil peluangnya untuk mengalihkan hak atas tanah dibandingkan dengan responden yang berusia kurang dari 40 tahun, namun hal ini tidak terlalu signifikan. Hal ini ditunjukkan oleh hasil ujinya yang belum signifikan dengan $p$-value sebesar 0.943 yang lebih besar dari 0.10 . Artinya usia seseorang yang mateng atau tidaknya tidak mempengaruhi petani akan mengalihkan asetnya atau tidak.

Petani penerima redistribusi tanah yang menjadi yang berjenis kelamin laki-laki cenderung lebih berpeluang untuk mengalihkan hak atas tanah 5.2 kali dibandingkan dengan responden perempuan, dan peluang tersebut dinyatakan signifikan signifikan yang ditunjukkan oleh p-value sebesar 0.073 yang lebih kecil dari 010 dan z-value (1.79) lebh besar dari 1.64. Artinya kaum lelaki/Bapak-Bapak lebih besar potensinya untuk mengalihkan SHM atau menjual tanahnya dibandingkan kaum wanita atau Ibu-Ibu. Hal dapat disebabkan oleh beberapa hal, antara lain pertama sebagai kepala rumah Bapak-Bapak cenderung lebih dominan dibandingkan ibu dalam mengambil keputusan, kedua secara psikologis kaum laki-laki lebih berani ambil risiko dan berpikir praktis, sedangkan kaum wanita dalam mengambil keputusan untuk menjual tanah atau menjual barang milik apalagi SHM lebih menimbang-nimbang dan memiliki rasa sayang terhadap barang dibandingkan kaum laki-laki.

Responden yang memiliki bidang tanah lebih dari satu lebih berpeluang tidak lebih berpeluang untuk mengalihkan hak atas tanah dibandingkan dengan responden yang memiliki satu bidang tanah saja hanya 0.29 , namun peluang tersebut dinyatakan masih belum signifikan yang ditunjukkan oleh $p$-value sebesar 0.126 yang lebih besar dari 0.327 . Artinya ada potensi, bahwa petani yang hanya memiliki 1 bidang tanah dengan catatan kesejahteraannya kurang atau dalam kategori 
sangat miskin berpeluang mengalihkan SHM atau menjual tanahnya untuk memenuhi kebutuhan hidupnya.

Responden yang bermitra dengan petani lebih ber-peluang 3.466 kali untuk mengalihkan hak atas tanah dibandingkan dengan responden yang memiliki satu bidang tanah saja, atau dengan kata lain responden yang tidak bekerjasama lebih berpeluang untuk tidak mengalihkan tanah dibandingkan responden yang melakukan kemitraan dengan petani. Namun demikian peluang tersebut dinyatakan masih belum signifikan yang ditunjukkan oleh $p$-value sebesar 0.218 yang lebih besar dari 0.10. Artinya bermitra atau tidak petani penerima redistribusi tanah tidak mempengaruhinya dalam keputusan untuk mengalihkan SHMnya ke pihak lain, walau yang bermitra lebih memiliki peluang lebih besar.

Memang pada kenyataan di lapangan yang penulis alami, petani yang berusaha dengan cara bermitra lebih membutuhkan modal yang besar dan usaha di bidang agribisnis juga mempunyai risiko gagal yang cukup besar. Kadang-kadang kegagalan usaha dan kerugian dapat menimbulkan hutang, sehingga untuk menopang beban hidupnya dan membayar hutang, apalagi ke pihak lain yang bukan bank atau digadaikan petani dengan terpaksa menjual asetnya atau mengalihkan SHMnya ke pihak lain. Ditambah lagi petani kita kebanyak berpendidikan rendah dan merasa sulit atau enggan berurusan dengan bank.

Petani dengan tingkat kemiskinan $\left(\mathrm{X}_{6}\right)$ tinggi atau masuk kategori paling miskin di kelompoknya lebih berpeluang mengalihkan SHM ke pihak lain dibandingkan terhadap petani yang memiliki tingkat kemiskinan rendah (paling kaya) di kelompok penerima redistribusi tanah sebesar 3.57 kali dibandingan yang lebih kaya atau peluang petani yang lebih kaya hanya 0.28 kali dibandingkan dengan lebih miskin di kelompok penerima redistribusi tersebut. Hal ini terbukti secara signifikan dengan p-value 0.03 dibawah 0.1 . Artinya petani yang lebih miskin berpotensi besar untuk mengalihkan SHM nya ke pihak lain, semakin petani tersebut dan terhimpit maka peluangnya untuk mengalihkan lahan lebih besar.

Hal tersebut sejalan dengan hasil penelitian Ida (2005) yang menyatakan bahwa tanah merupakan aset yang dapat digunakan oleh masyarakat miskin uantuk mendapatkan akses ke aset lain. Karena akses tanah yang diperoleh dapat memudah untuk dijual atau dipindahkan tangankan atau dijadikan jaminan untuk usaha-usaha yang produktif. Namun pada kenyataannya masyarakat kita sering mencari jalan pintas dengan cara digadaikan ke perorangan yang tidak pakai prosedur yang sulit. Bhatta (2010) pun mengungkapkan hal yang sama bahwa dampak darilandreform dan redistribusi tanah akan memberikan keuntungan bagi sosial dan ekonomi bagi rakyat miskin.

Ada atau tidaknya peran atau pengaruh dari pihak luar $\left(\mathrm{X}_{7}\right)$ tehadap keputusan petani mengalihkan SHM mengalihkan SHM ke pihak lain. Berdasarkan hasil regresi logistik tabel di atas menunjukkan adanya pengaruh/peran dari pihak luar berpeluang sangat besar mencapai 648 kali dibandingkan yang tidak dipengaruhi dalam menentukan keputusan untuk mengalihkan SHMnya kepada pihak lain. Hal ini ditunjukkan oleh p-value sebesar 0.00 dan z-hitung sebesar 3,95 serta odd rationya. Artinya pengaruh pihak luar signifikan dalam mempengaaruhi petani dalam mengambil keputusan pengalihan SHM ke pihak lain.

Mengingat pengaruh pihak luar signifikan terhadap pengalihan SHMnya ke pihak lain, maka sudah seharusnya pemerintah melakukan pendampingan terhadap program-program sejenis, khususnya kepada petani pemegang SHM hasil redistribusi agar tidak dipengaruhi pihak lain. Pemerintah juga dapat melakukan penyuluhan-penyuluhan atau meyediakan tenaga penyuluh daerah (TPD) seperti yang dilakukan Kementerian Perikanan pada program pengembangan ekonomi wilayah pesisir (KKP 2015).

\section{SIMPULAN}

Responden yang diteliti mayoritas berpendidikan lebih dari SD (51.8\%), berumur lebih dari 40 tahun (60.2\%), berjenis kelamin lak-laki (74.7\%), memiliki lebih dari 1 (satu) bidang tanah (50.6\%) dan melakukan kerjasama dengan kelompok tani (74.7\%). memiliki tingkat kemiskinan yang tinggi mencapai $73,5 \%$ dan bagi petani yang telah mengalihkan SHM kepihak lain sebagian besar dipengaruhi pihak luar.

Isu petani mengalihkan sertipikat kepada pihak lain pada peserta program legalisasi aset kegiatan redistribusi tanah di desa tassoko kecamatan karossa Kabupaten Mamuju memang sudah terjadi, namun tidak teralu besar. Jumlah petani yang sudah mengalihkan sertipikatnya dengan cara menjual kepada pihak lain mencapai sebanyak $28.9 \%$, sedangkan yang belum mengalihkan lahannya kepada pihak lain (71.1\%). Hal ini tidak dapat diaggap sepeleh, karena apabila dibiarkan akan terus berlanjut, semakin banyak SHM yang berpindahtangan berarti semakin tidak sukses program redistribusi pemerintah yang bertujan mengentaskan kemiskinan.

Faktor penentu yang mempengaruhi keputusan petani mengalihkan sertipikat tanah hasil program retribusi adalah Jenis Kelamin laki-laki, Tingkat Kemiskinan dan Pengaruh Pihak luar, sedangkan empat faktor lainnya yakni pendidikan, umur, jumlah bidang tanah yang dimiliki dan kerjasama dengan kelompok tani tidak berpengaruh terhadap keputusan petani untuk mengalihkan sertipikat kepada pihak lain. Hal ini dikarenakan kaum laki-laki dominan dalam pengambilan keputusan dan lebih berani dalam mengambil risiko, sedangkan perempuan umum lebih hati-hati dalam memindahtangankan aset yang sangat berharga. Selain itu, tingkat kemiskinan petani penerima program redisribusi tanah yang tinggi atau sedang mengalami 
himpitan ekonomi lebih berpotensi untuk orang berpikir pendek dengan cara menjual aset yang ada, dibandingkan petani yang ebih mapan. Demikian juga dorongan atau pengaruh pihak luar, misalnya imingiming lebih besar pengaruh terhadap keputusan petani untuk mengalihkan sertipikat kepada pihak lain

\section{DAFTAR PUSTAKA}

BhattaGP. 2010. Assessing land reform approaches to benefit Socially and Economically Disadvantage (SED) people [disertasi]. Nederlands (US): International Institute For Geo-Information Science and Earth Observation Enschede.
Borras Jr, Saturino, Fanco, Jenifer C. 2008. Land Policy and Governance; Gaps and Challenges in Policy Studies. Oslo Governance Centre Brief 1 UNDP.

Soetrisno L. 1995. Menuju Partisipasi Masyarakat. Yogyakarta (ID): Kanisius 